\title{
船渠海水中における 200kHz 超音波吸収減東
}

\author{
柴田、恵 司 ${ }^{*}$ \\ Some Observations of Ultrasonic Absorption \\ in Water of Ship Yard Dock
}

K. Shibata

\begin{abstract}
The air bubbles occur in various forms in the sea, and they are generated also in wakes of ships where they are known to remain for long periods of time. Especially, great amounts of air.bubbles are generated in the dock water by pouring water and by discharging currents of tag-boats in which high value of ultrasonic absorption is presumed.

Observations of ultrasonic absorption in dock water were carried out in the No. 2 Dock of Nagasaki Ship Yard of Mitsubishi Heavy Industry Co., in February 1970.

After observations, the absorptions caused by air bubbles and others in dock water were estimated as $0.05 \mathrm{~dB} / \mathrm{m}$ to $0.35 \mathrm{~dB} / \mathrm{m}$, and $0.13 \mathrm{~dB} / \mathrm{m}$ in average. Those values were far high beyond the predicted one.

\section{緒言}

海水中における超音波の吸収減衰は水中音響測器の性能を制限する要素の一つであり, 減衰係 数 $\alpha$ は一般に周波数に従つて変動するが, 媒質（海水）中に抢ける気泡の存在も減衰に奇与す る。海水中に捛汀る気泡の分布の代表的なものは航走中の船舶のウエーキの中に見られ，その気 泡が長時間海水中に残留することも知られている。[1～3]

船渠内における超音波吸収減衰について明らかにするため，三菱重工長崎造船所第二船渠にお いて水平に送受された $200 \mathrm{kHz}$ 超音波による計測を行なつた。

船渠中の海水の場合，風浪抒よび潮汐流の影響は極めてわずかであるが，注水拉よび曳船によ る気泡の発生が多く，又これらの他，出入渠船によつて生ずる海水の不規則な流れも見られる。

測定結果から見ると, 気泡に基づくと思われる超音波減衰は必ずしも一定ではなく $0.05 \mathrm{~dB} / \mathrm{m} \sim$ $0.35 \mathrm{~dB} / \mathrm{m}$ の間 (平均 $0.13 \mathrm{~dB} / \mathrm{m}$ ) に分布していた。

1. 船渠内の海水

実験を行なつた船渠の門偝附近においては注水開始後約 4 時間の間, 渠内水位が閒扉注水孔位 置より低いため海水に大量の気泡を生じ白濁した状態であり, 門扉開放後は接近した曳船推進器 の排出流によつて部分的に気泡による白濁が観察された。気泡寸法や分布密度に関する観察は全 く行なわれなかつたが, 渠内海水の溶存酸素の測定によつて閒接的に気泡密度の時閒的変化を推
\end{abstract}

* 長崎大学水産学部（長崎市文教町 1-14） 
察しようとした。溶存酸素量は第 1 表に示す。注水開始 5 時間後では海水はやや白濁しており， 溶存酸素量は $4.6 \mathrm{~m} l / l$ と船渠外海水の $3.3 \mathrm{~m} l / l$ に較べ可成り高い。又この後白濁した状態は時 間の経過と共に消失するが, 溶存酸素量も徐々に減少して 6 時間後には $3.9 \mathrm{~m} l / l$ に安定した。 門屝開放直後では $4.08 \mathrm{~m} l / l$ とやや高くなり, 出渠後では $3.3 \mathrm{ml} / l$ と外海水と等しい值を示し た。尚 $3.3 \mathrm{~m} l / l$ の溶存酸素量は外洋水に較べて著しく低いが，これは長崎港の海水中に多量の 有機成分を含有していることを示すものと考える。又当時の海水中の塩分は $28 \%$ であり，比重は 1.020 と推定される。

\section{2. 測定の方法および結果}

浅海用精密測深機 (SD1500型) によつて超音波を岸壁から水平方向に送受し，反対 側 の 岸壁 （56m）に直角に入射し得る如くした。

送受波器各 1 個は上下に相接して固定され，満水時に扔いて約 $2 \mathrm{~m}$ の深度に固定された。この 音源位置は水平距離で閃扉内側より $8 \mathrm{~m}$ 入渠船舵板後端から $1.6 \mathrm{~m}$ であつた。

測定は音源から $56 \mathrm{~m}$ の対岸および $28 \mathrm{~m}$ の舵板からの反射波音圧および任意の距離におうるる雑音 音圧について行なわれた。

\section{1 岸壁の標的強度}

コンクリートの岸壁の表面は波長に較べて充分平滑であり，超音波ビームに較べ充分な面積を 持つと考えた。一般に無限平面の標的強度は $10 \log \left(\frac{r}{2}\right)^{2}$ で示されている。ここでては音源までの 距離を示す。そこで船渠岸壁の標的強度は

$$
\begin{aligned}
& T s=10 \log _{10}\left(\frac{r}{2}\right)^{2} \overline{T R^{2}} \ldots \ldots \ldots \ldots \ldots \ldots \ldots \ldots \\
& T R=\left(\rho_{1} C_{1}-\rho_{2} C_{2}\right) /\left(\rho_{1} C_{1}+\rho_{2} C_{2}\right)
\end{aligned}
$$

である。ここで $\rho_{1} C_{1}$ および $\rho_{1} C_{2}$ はそれぞ れ海水と反射体の密度および音速度である。 $\rho_{1} C_{1}=1490 \times 1.02[3], \rho_{2} C_{2}=3600 \times 2.2[4]$ とすると。岸壁と音源の間の距離 $r=56 \mathrm{~m} て ゙$ あるから，(1)により $T s=+25 \mathrm{~dB}$ となる。

舵板の場合，超音波ビーム主軸から約 $3.5^{\circ}$ 外れているため, 舵板からの反射音圧の最大 值を基準とする事にした（Ts=+22dB）。従 つて舵板からの反射音圧を用いた結果は必ず しも正確なものではない。

\section{2 気泡に起因する吸収減衰}

岸壁の最大反射音圧は, 出渠作業後, 渠内 海水が外海の状態と同じ溶存酸素量 $3.29 \mathrm{~m} l / l$ になつた時 $80 \mathrm{~dB}$ として得られた。この值を 基集として音源音圧を求める。ソナー方程式 に抒いて

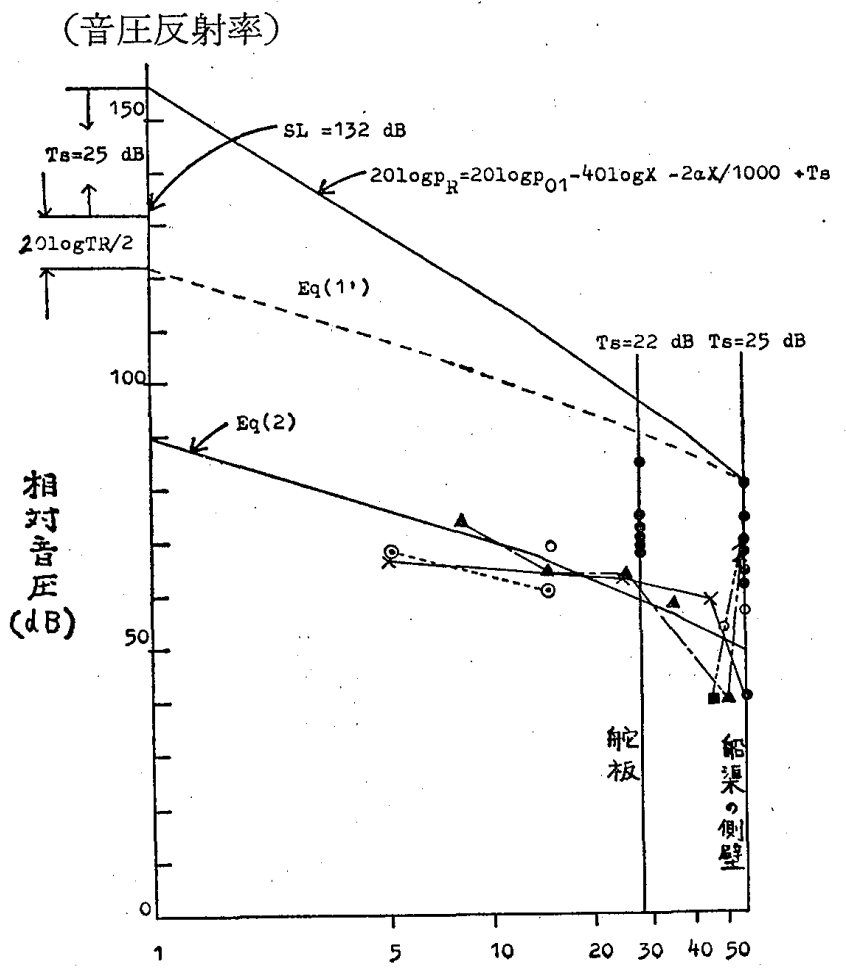

第 1 闵 第 2 船渠に拈ける测定結果

$20 \log _{10} p_{R}=20 \log -20 \log _{10} 2 x-2 \alpha x / 1000+20 \log _{10} \overline{T R}\left(1^{\prime}\right)$ $20 \log _{10} p_{R}=20 \log _{10} p_{01}-20 \log _{10} x-2 \alpha x / 1000+$ $10_{10} \log (\tau c / 2)+10 \log _{10} \psi$ 
$20 \log _{10} p_{R}=20 \log _{10} p_{01}-40 \log _{10} x-2 \alpha x / 1000+T s$

ここで, 岸壁までの距離は $x=56 \mathrm{~m}$, 岸壁の標的強度 Ts 注 $+25 \mathrm{~dB}$, 最大反射信号の相対音圧 は $80 \mathrm{~dB}$ であるから，吸収減衰係数 $\alpha=0.05 \mathrm{~dB} / \mathrm{m}$ とすると(2)式から

$80=20 \log _{10} p_{01}-70-5.6+25$,

$20 \log _{10} p_{01}=131 \mathrm{~dB}$

が得られる (Fig 1 参照)。そこで本機の指標点における音源音圧を $131 \mathrm{~dB}$ として考察を進める 事にする。

測定結果は第 2 表执よび Fig 1 に示す通りである。本表に沶ける標的強度 $T s^{\prime}$ および海水の体 積散乱強度は何れも観測結果を示すものであり，気泡に基づく吸収減衰の全量は $\left(T s-T s^{\prime}\right)$ であ ると考光， $K=\left(T s-T s^{\prime}\right) / 2 x$ から吸収減衰係数 $K$ を算出した。

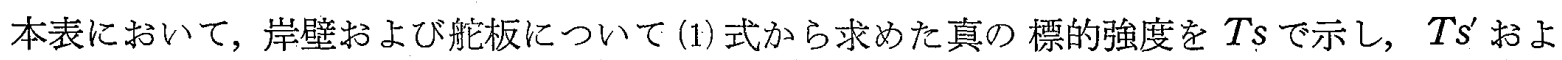
び $T s^{\prime \prime}$ は(2)式から求めた標的強度である。又 $K_{1}$ は音源から岸壁までの間に拈ける平均減衰係数 $K_{1}=\left(T s-T s^{\prime}\right) / 112 \mathrm{~m}^{\prime}(\mathrm{dB} / \mathrm{m}), K_{3}$ は音源加ら舵板までの平均減衰係数を示す。又 $K_{2}$ はほとん ぞ等時的に 行なわれた 舵板の観測から求めた $K_{3}$ を加味した舵板から対岸の 岸壁までの 值であ る。

\section{3 渠内雑音の体積散乱強度}

観測渠内海水中に多くのノイズが見られた。これらは何れも気泡群による散乱であるとして体 積散乱強度 $S_{V}$ [2]，（多くの散乱体を含む海水 $1 \mathrm{~m}^{3}$ 当りの反射の強さ）を次式〔2]により求め た。

$20 \log _{10} p_{R}=20 \log p_{01}-40 \log _{10} x-2 \alpha x+S_{V}+10 \log _{10} V$

ここで, $V=\frac{\tau C}{2} \phi x^{2}$ 注積 $x^{2} \psi$ の断面 (入射方向に直危) を持つ長さ $\frac{\tau C}{2}$ の円筒の体積であり, 又理想ビームパターンの開角 $\phi$ (ステラジアン) の中ではすべて等価の反射音圧が得られ，その外 では全く反射に寄与しない範囲を示す。即ち $\phi$ は橋本 $[5]$ 年定義した有効角 $\theta_{0}$ とほぼ等価のも のであり, 次式[2]によつて示される。

$$
10 \log _{10} \phi=10 \log \int_{0}^{2 \pi} \int_{-\pi / 2}^{\pi / 2} R_{R}{ }^{2}(\theta, \varphi) R_{S}{ }^{2}(\theta, \varphi) \cos \theta \mathrm{d} \theta \mathrm{d} \varphi
$$

この音響測探機の円筒振動子 $(2 \mathrm{a}=10 \mathrm{~cm}, \lambda=0.75 \mathrm{~cm})$ については,

$$
10 \log _{10} \phi=20 \log _{10}(\lambda / 2 \pi \mathrm{a})+7.7=-24.7 \mathrm{~dB}
$$

である。又(3)式から

$$
20 \log p_{R}=20 \log p_{01}-40 \log x-2 \alpha x / 1000+10 \log \frac{\tau C}{2}+10 \log \phi+20 \log x
$$

従つて

$$
20 \log P_{R}=20 \log P_{01}-20 \log x-2 \alpha x / 1000+10 \log \frac{\tau C}{2}+10 \log \psi
$$

ここで, 本実験の場合 $\frac{\tau C}{2}=0.4 \mathrm{~m}, 20 \log p_{01}=131 \mathrm{~dB}, \alpha=0.05 \mathrm{dBm}$ おふよび $10 \log \phi=-24.7 \mathrm{~dB}$ を(4)式に代入して

$$
S_{V}=102-20 \log P_{R}-20 \log x-0.1 x
$$

本測定において，直接得られるものは受波音圧 $20 \log p_{R}$ および距離 $x$ であるから，これらを(5) 式に代入すれば $S_{V}$ が得られる。

第 2 表における右欄は，超音波ビーム主軸上における各種の音源からの距離において見られた 水の体積散乱強度である。これらの位置と音源までの間の超音波伝播距離に対する減衰を前述の 


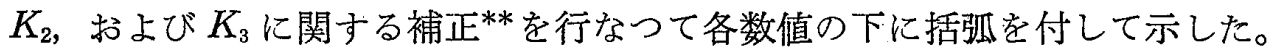
本表に示した結果から次の事が言える。

1. 門扉が開放されるまでの間は， $K$ は平均して $0.12 \mathrm{~dB} / \mathrm{m}$ であり， $K_{1}, K_{2}$ および $K_{3}$ の值が ほぼ近似している事から，渠内の海水中の気泡は比較的平均かつ安定した分布をしていると推 定される。(推定された平均気泡体積: $1 \mathrm{~cm}^{3}$ 当り $8.7 \times 10^{-7} \mathrm{~cm}^{3}$ )。又此の期間酸素量む $3.9 \mathrm{~m} l / l$ とほぼ安定していた。

2. $13^{20}$ 門屝が開放された後では曳船 2 隻が接近して随時推進器を作動させたからその排出流と これによつて生じた気泡群によつて気泡密度は空間的にも時閒的にも極めて不均質となつた。 従つて海水の体積散乱強度も部分的に著しく大きな洒を示した。

3. 等時的に測定された舵板又は，岸壁からの標的強度とそれぞれの計算標的強度との差が気泡 の存在に起因する吸収減衰であると仮定して求めた $K_{1}$ および $K_{3}$ の平均はそれぞれ $0.13 \mathrm{~dB} / \mathrm{m}$ および $0.12 \mathrm{~dB} / \mathrm{m}$ であつた。

** 1) 厳密には,これらの気泡層による吸収を見込まねばならない。

2）注水中および曳船が接近して運動する場合気泡を含んだ水塊の分布は極めて不規則かつ流動的である から約 1 分間隔で行なわれた岸壁舵板の観測は厳密には等価に比較出来ないかも知れない。

\section{結 論}

本実験の結果, 船渠中の海水には多量の気泡が分布し, 超音波の水中伝播において大きな障害 となる事が認められた。

1. 理想海水中の吸収減衰係数 $\alpha=0.05 \mathrm{~dB} / \mathrm{m}$ とした場合, 気泡層の分布に起因すると考えら れる吸収減衰係数 $K$ は $0.95 \sim 0.35 \mathrm{~dB} / \mathrm{m}$ であり平均して, $0.12 \mathrm{~dB}$ であつた。

2. 渠内海水中の雑音音圧は曳船が接近して推進器を作動させた場合，船体の反射音圧を超え る事もあつた。

3. 気泡を含む海水の体積散乱強度は $-83 \mathrm{~dB} \sim-66 \mathrm{~dB}$ ，平均してー73.5 dBであつた。 本実験に当り，観測用器材を快く提供して頂き実験に協力された海上電機 $\mathrm{KK}$, 有村浩氏およ び，種々御協力を賜つた長崎三菱造船所飯田幸吉船渠課長に厚く御礼を申し上げます。

\section{引用文献}

[1] Albers, V. M. : Underwater Acoustic Handbook, 2 (Book) State University Press (1965) p86-99

[2] URICK, R. J. : Principles of Underwater Sound for Engineers (Book) McGraw Hill (1967)

[3] 日刊工業新聞（実吉統一等）：超音波技術便覧（1960） p147-163

[4] 安斎太郎：日本音響学会講演論文集 (1958) p 87-88

[5] 橋本富寿：漁船研究室研究報告, (1955), 2

第 1 表 三菱造船第二船渠中の海水の情況と作業状態

\begin{tabular}{|c|c|c|c|}
\hline 時 刻 & 水。温 & $\begin{array}{c}\text { 溶存酸素量 } \\
\mathrm{ml} / 1\end{array}$ & 考 \\
\hline $11-20$ & 12.2 & 3.30 & 門屝外海水 \\
\hline $11-45$ & & & 下松丸がばん木から浮上 \\
\hline $12-00$ & 13.1 & 4.64 & 渠内海水はこのころまで白濁している \\
\hline $12-30$ & 13.3 & 3.92 & \\
\hline $13-13$ & & & 船渠戸開放開始 \\
\hline
\end{tabular}




\begin{tabular}{|c|c|c|c|}
\hline $13-18$ & & & 開放終了 \\
\hline $13-25$ & & & 曳船 2 隻接近して电索をとる \\
\hline $13-38$ & 13.1 & 4.04 & 曳出乙開始 \\
\hline $13-55$ & & & 作業完了 \\
\hline $13-58$ & 13.0 & 3.29 & \\
\hline
\end{tabular}

第 2 表 船渠内海水中にお汸る吸収減衰

\begin{tabular}{|c|c|c|c|c|c|c|c|c|c|c|c|c|}
\hline $\begin{array}{l}\text { 時 刻 } \\
12-50\end{array}$ & $\begin{array}{r}\mathrm{Ts}^{\prime} \\
0\end{array}$ & $\begin{array}{c}\mathrm{Ts}-\mathrm{Ts}^{\prime} \\
25\end{array}$ & $\begin{array}{c}\mathrm{K}_{1} \\
0.22\end{array}$ & $\mathrm{~K}_{2}$ & $T s^{\prime \prime}$ & $T s-T s^{\prime \prime}$ & $\mathrm{K}_{3}$ & $5 \mathrm{~m}$ & \multicolumn{3}{|c|}{$\begin{array}{l}\text { 気泡群の体積散乱強度 } \\
15 \mathrm{~m} \quad 25 \mathrm{~m} \quad 35 \mathrm{~m}\end{array}$} & $45 \mathrm{~m}$ \\
\hline $12-55$ & $14 \sim 18$ & $7 \sim 11$ & $0.06 \sim 0.10$ & - & 10 & 12 & 0.21 & & & & & \\
\hline $13-00$ & 8 & 17 & 0.15 & 0.21 & 17 & 5 & 0.09 & & & & & \\
\hline $13-03$ & 13 & 12 & 0.11 & 0.13 & 17 & 5 & 0.09 & & & & & \\
\hline $15-05$ & 14 & 11 & 0.10 & 0.05 & 14 & 8 & 0.14 & & & & & \\
\hline $13-13$ & 14 & 11 & 0.10 & 0.11 & 17 & 5 & 0.09 & & & & & \\
\hline $13-18$ & & & & & & & & $\begin{array}{l}-79 \\
(-78)\end{array}$ & $\begin{array}{c}-76 \\
(-73)\end{array}$ & & & \\
\hline $13-24$ & 14 & 11 & 0.10 & & & & & & & & & $\begin{array}{c}-83 \\
(-75)\end{array}$ \\
\hline $13-27$ & -16 & 14 & 0.37 & 0.61 & 15 & 7 & 0.13 & $\begin{array}{c}-80 \\
(-77)\end{array}$ & & $\begin{array}{c}-69 \\
(-62)\end{array}$ & & $\begin{array}{l}-65 \\
(-33)\end{array}$ \\
\hline $13-31$ & 8 & 17 & 0.15 & 0.14 & 13 & 9 & 0.16 & $\begin{array}{l}3-69 \\
(-66)\end{array}$ & $\begin{array}{c}-74 \\
(-69)\end{array}$ & $\begin{array}{l}-78 \\
(-60)\end{array}$ & $\begin{array}{c}-69 \\
(-57)\end{array}$ & $\begin{array}{l}-80 \\
(-65)\end{array}$ \\
\hline $13-35$ & 14 & 11 & 0.10 & & & & & & $\begin{array}{l}-69 \\
(-66)\end{array}$ & & & \\
\hline $13--50$ & 24 & 1 & 0.01 & & & & & & & & & \\
\hline $14-00$ & 25 & 0 & & & & & & & & & & \\
\hline Average & & & $\underline{0.13}$ & $\underline{0.20}$ & & & $\underline{0.13}$ & & & & & \\
\hline Ts : 計 & 算による & 標的強度 & 船渠壁 & $25 \mathrm{~dB}$ & 板 2 & & & & & & & \\
\hline $\mathrm{T}_{\mathrm{s}} \mathrm{s}^{\prime}$ : 測 & 定による & 標的強度 & 船渠壁 & & & & & & & & & \\
\hline Ts"：測 & 定による & 禋的強度 & 舵板 & & & & & & & & & \\
\hline
\end{tabular}

\section{[質問]}

1） $200 \mathrm{kHz}$ の超音波の吸収減衰 $0.05 \mathrm{~dB} / \mathrm{m}$ と仮定してあるが，気泡がなくなつたと思われるよ うな定常状態において測定した值を用いるべきではないか。

3）ドックの中の水注気泡以外の得濁物も多いと考えられ，超音波の吸収，散乱は，これらのよ る総合的なものであるから， $0.05 \mathrm{~dB} / \mathrm{m}$ 以外の減衰をすべて気泡の影響と考えるのは問題があ るのではなかろらか，質問 1）の值を測定しておけば，この問題が解決できるのではなかろう か。

（飯島幸人）

\section{[解答]}

1）確かに御説の通りです。標準反射体による計測を行なつた結果，室内実験におけるような充 分な精度が得られなかつたので，残念ながら $\alpha=0.05 \mathrm{~dB} / \mathrm{m}$ の值を用いました。

既に述べているごとく, 作業完了後渠外海水が流入し, 安定した状態において計測した渠壁 echo を基準にしていますから殆んど外海水中と同じ結果が得られたと思います。

又 $\alpha=0.05 \mathrm{~dB} / \mathrm{m}$ は $S=35 \%$ に拈ける值ですが，本計測においては $S=28 \%$ o $\left(\mathrm{Mg} \mathrm{SO}_{4}\right.$ は 測定してない) ですから, 正確には $\alpha=0.043 \mathrm{~dB} / \mathrm{m}$ と推定されます。従つて此の点から見る 
と若干過大に見積られた傾向があります。

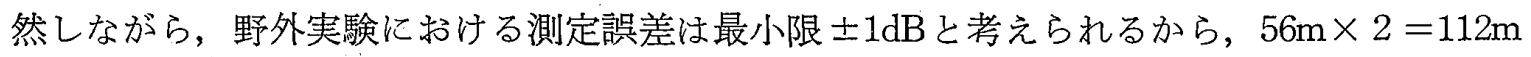
の伝播距離を考慮しても $\alpha=0.05 \mathrm{~dB} / \mathrm{m}$ と仮定したことに基づく誤りは計測誤差の中に含まれ ると推察いたしました。

2）本測定が行なわれた冬期における透明度は $6 \mathrm{~m}$ （長崎港外では冬期 $18 \mathrm{~m}$, 夏期 $10 \mathrm{~m}$ ）であり， 夏の $3 \mathrm{~m}$ に較べて可成り清澄です。此の程度の海水中にある賏濁物の超音波伝播に対する影響 については未だ明らかにされていないが，今後機会あり次第明らかにしたいと思います。

本計測の目的は御説の通り “総合的な減衰 $(\alpha+K)$ の最大值を推定し, 機器設計の基礎資 料とすることであり，極論すると， $\alpha=0.35+0.05=0.4 \mathrm{~dB} / \mathrm{m}$ を得ることが目的であつたと考 えます。 